8. Шаховский В.И. Категоризация эмоций в лексико-семантической системе языка. Москва : ЛКИ. 2008. C. 88-93.

9. Шевченко І.С. Дискурс як когнітивно-комунікативний феномен : монографія. Харків : Константа, 2005. 356 c.

10. Шейгал Е.И. Градация в лексической семантике : учеб. пособие к спецкурсу. Куйбышев : Изд-во Куйбышевского гос. пед. ин-та. 1990. С. 12.

11. Leith S. You Talkin' To Me? Rhetoric from Aristotle to Obama. London : Profile Books. 2012. 296 p.

12. Tannen D. Men and Women in Conversation is Cross-Cultural Communication : вебсайт. URL: http://faculty.georgetown.edu/bassr/githens/tannen.htm (дата звернення: 18.12.2019).

13. Sheldon S. Nothing Lasts Forever. United Kingdom : Harper Collins. 1995. 384 p.

\title{
UMBERTO ECO'S POSTMODERNISM AND POSTMODERN REVERBERATION OF INDEPENDENCE PERIOD OF AZERBAIJAN LITERARY PROSE
}

\section{ПОСТМОДЕРНІЗМ УМБЕРТО ЕКО ТА ВІДЛУННЯ ПОСТМОРДЕРНІЗМУ В ПЕРІОД НЕЗАЛЕЖНОСТІ В АЗЕРБАЙДЖАНСЬКІЙ ХУДОЖНІЙ ПРОЗІ}

\author{
Ismayilova Nargiz, \\ orcid.org/0000-0001-5740-6237 \\ Big scientific researcher \\ of the Institute of Art, Language and Literature \\ of the Nakhchivan Branch of the Azerbaijan Academy of Sciences
}

The work of the postmodern philosopher and writer Umberto Eco, an integral part of modern Western thought, plays a significant role in world literature. Umberto Eco's "Art and Beauty in the Middle Ages" (1987), "Six Walks in the Fictional Woods" (1993), "The Name of the Rose", one of the most important examples of intellectual postmodernism and 20th-century novelism. The novel "Foucault's Pendulum" (1988), "The Island of Day Before" (1994), taken as an example of paste, should be explored in the context of postmodern literature theory comparatively with Azerbaijani literature.

The postmodern wave, the product of recent times in Azerbaijani literature, examines the fascinating influence and prism of Western literature, and we find that Umberto Eco, a well-known European thinker in the literature arena, is the most popular postmodern wave in the world. Eco's intellectual postmodernism has resonated deeply in Azerbaijani literature. Among the works that come from this aspect are the work of Kamal Abdulla's "Incomplete Manuscript". However, I should note that the postmodernist works also appear in Azerbaijani literature, in terms of service to the development of national literature, through the filtering of our folklore, myths and epics back into the postmodern era, and without re-appreciating the old ways of Azerbaijan. It offers clear solutions to many of its society's thinking problems. There are no exceptions.

From this aspect, Umberto Eco creativity plays a unique role in the formation of postmodern artistic thinking in Azerbaijan. Above the center, in absolute relativity, in truth, in truth, in doubt, in denial of gravity on analysis, mystery, intertextuality, semiotics, etc. The concepts are reflected in the novel "The Name of the Rose". The concept of interethnic or intertextuality brought to mind Mikhail Bakhtin. Intertextual relations are based on the law of the most general definition of a text with pre-written texts. The novel "The Name of the Rose" is more important than the information aspect. Interesting points about many historical figures that are included here have been developed in parallel with the real and mythical ideas.

Key words: Umberto Eco, postmodernism, Azerbaijani literature, comparison, analysis, postmodern prose, text.

Твір постмодерного фрілософа та письменника Умберто Еко - невід'ємна частина сучасної західної думки, що відіграє значну роль у світовій літературі. «Мистецтво і краса в Середньовіччі» Умберто Еко (1987), «Шість прогулянок у вигаданому лісі» (1993), «Ім'я троянди» - одні із найважливіших прикладів інтелектуального постмодернізму та новелістики XXX століття. Роман «Маятник Фуко» (1988), «Острів напередодні» (1994) взяті як приклад пасти. Їх слід досліджувати в контексті постмодерністської теорії літератури у порівнянні з азербайджанською літературою.

Останнім часом в азербайджанській літературі досліджується захоплюючий вплив західної літератури. На думку автора, Умберто Еко - відомий європейський мислитель на арені літератури - є найпопулярнішою постмодерністською хвилею у світі. Інтелектуальний постмодернізм Еко глибоко резонував в азербайджанській літературі. Серед робіт, які виходять із цього аспекту, - твір Камаля Абдулла «Неповний рукопис». Однак, постмодерністські твори також з'являються в азербайджанській літературі служіння розвитку національної літератури через фільтрацію фольклору, міфів та епосів назад в епоху постмодерну та без переоцінки старих шляхів Азербайджану. Він пропонує чітке рішення багатьох проблем мислення в суспільстві. Винятків немає.

Творчість Умберто Еко відіграє унікальну роль у фрормуванні постмодерністського художнього мислення в Азербайджані над центром, в абсолютній відносності, істині, сумніві, у запереченні тяжкості, таємничості, інтертексту- 
альності, семіотиці. Ці концепції відображені в романі «Ім'я троянди». Інтертекстуальні відносини ґрунтуються на законі найбільш загального визначення тексту з попередньо написаними текстами. Роман «Ім'я троянди» важливіший за інформаційний аспект. Цікаві моменти про багатьох історичних постатей, які тут включені, були розроблені паралельно з реальними та міфічними ідеями.

Ключові слова: Умберто Еко, постмодернізм, азербайджанська література, порівняння, аналіз, постмодерністська проза, текст.

Introduction. Above the center, in absolute relativity, in truth, in truth, in doubt, in denial of gravity on analysis, mystery, intertextuality, semiotics, etc. The concepts are reflected in the novel "The Name of the Rose". The concept of interethnic or intertextuality brought to mind Mikhail Bakhtin. Intertextual relations are based on the law of the most general definition of a text with pre-written texts. Interpersonalism is one of the methods of postmodernism's text analysis. "In terms of interdependence, each text is constructed as a mosaic of meanings, and each text is a transformation of another text. To put it simply, intertextuality is not a system where text and text reading are independent and that everything is in the text, there are other texts and other readings as well. And, in fact, every text is linked to other texts. Not every text actually exists on its own, but rather contains other codes and texts" [13, c. 207].

The texts created by Eco, which provides the most important examples of postmodernism in the world literature, are interesting in terms of intertextuality. "Intertextuality is one of the terms most commonly used in terms of definition and meaning difficulty. Incorporation of literary texts from both literary and other fields in order to be integrated into a whole structure" [2, c. 1667].

The intertextuality, the framework, the boundary, and the boundary of what is described in the general sense appear as an unattainable method. "The concept was first revealed in 1965 by French writer Julia Kristeva" Julia Kristeva (1972). Gerard Genette, one of the leading representatives of French writing science and interpretation, explores the topic of "interdependence" in his work Palimpsests (Palimpsestus) under the heading "transtex-tuality", and adds "hypertextuality" [1, c. 154].

Thus, intertextuality appears as a key component of postmodern works. The novel "The Name of the Rose" is more important than the information aspect. Interesting points about many historical figures that are included here have been developed in parallel with the real and mythical ideas. As you read the book, it becomes more difficult to choose between the realities and the myths. "The Name of the Rose" begins with the discovery of a manuscript that reflects the "metaphorical" effects of postmodernism and the notes that the work was taken from that manuscript. Jorge, an old monk who is hiding in a secret compartment in the monastery, trying to prevent anyone who has never read a book before, secretly leads to the death of seven monks. This book is a missing part of Aristotle's Poetry. One type is "Poetics". The author here informs those who misunderstand postmodernism in order to inform the dangers that await those who want to break away from the past, saying that postmodernism is not about breaking away from tradition, but about innovating in ways that are not so dangerous.

In the text of the fantasy of the seven days, seven people are killed and killed in a mysterious way, every day. Wilhelm, a former court officer, accepts the crime-solving work offered to him at this monastery where his crimes go to a congregation. Wilhelm, a carpenter in the large library of the monastery, GreekArabic translator Venantius, Benno, library assistant Brengar, Aymora, who copied the manuscripts, Malachi, a librarian, and the murderer of Severinus, a specialist in healing herbs, investigated the cause. As we have seen, the real facts in the work are intertwined with the device.

"Although the main character is Wilhelm of Baskerville, the events are told by his student, Adson. Baskerville created the image of Eco, who also benefited from Doyle's "Sherlock Holmes" for Wilhelm's image, and was influenced by Dr. Watson, who was also Assistant Professor of Sherlock Holmes. "Adson's description of Wilhelm at the beginning of the book is almost exactly the same as Watson's portrayal of Sherlock. The fact that Adson is Melkly is associated with one of the most popular middle-class libraries in the area. And for Jorge, another important figure in the novel, he was inspired by the Austrian writer Jorge Borghez. The Book of the Babylonian Library, a short story by X. Borchez, gave an idea for Eco's mysterious library idea.

Analysis of recent research and publications. In many postmodern texts, the concept of search, the occurrence of events around a search string, and the reader's attempt to make it a part of the story are also popular. We also become part of the same motives in the work of Kemal Abdulla's The Unfinished Handwriting. The unfinished manuscript also follows events in the background of the investigation by Bayan khan. The investigation is also underway. Looking for a culprit. In both works, the investigator actually understands 
the matter, knows its essence well, but the purpose of this search is to go to the depths, which sometimes confuse his brain. In both works the true culprit is perfectly concealed from the reader. The reader also joins the writer and is looking for a sinner. In both works, the writer is a researcher of the true nature of the re-text. Eco da Kemal Abdullah also knows the text. In both works, the reader is reminded of the manuscript of the work.

Umberto Eco was born on 5 January 1932 in Alessandria, a small town in northern Italy. The Eco surname, meaning "a gift from paradise," has been well-regarded by the city's pioneers. Umberto's childhood was very difficult financially. Umberto, who continued his studies at a Catholic school, later studied at the University of Turin in the fields of Medieval philosophy and literature. Eco, who was appointed associate professor at the University of Turin in 1962, later marries Renat Ramgell, art historian. In 1969 he was appointed professor at the University of Florence. He holds countless conferences in many European universities and in America. He then makes his presentations at conferences. Late in his life, he has been battling cancer. February 19, 2016 he has died.

1. Along with his works such as "Art and Beauty in the Middle Ages" (1959), "Wrong Reading" (1963), "The History of Beauty", and (2004) "The History of Bliss" (2007), he has written many important novels:

1. "The Name of the Rose" (1980).

2. "Foucault's Pendulum" (1988).

3. "The Island of Day Before" (1994).

4. "Baudolino" (2000). "The Mysterious Flame of Queen Loana" (2004).

5. "The Prague Cemetery" (2010).

Discussion. After the first edition of the Umberto Eco classic. "The Name of the Rose" in 1980, it was greeted not only by Europe but also around the world. In a short period of time, many investigations into the work began, and the film was shot. And for the first time in this work, history went from being a background issue to the center of the work. His views on medieval Europe, one of the most frequently discussed topics in academic research and conferences, have drawn worldwide attention. He said that he thought that this era, coincided with the negative aspects of the Inquisition, was actually the time when the foundations of modern Europe were laid. Eco's thinking system was to challenge and believe in the new theory of relying on the old, rather than rejecting the old with radicalism and building new ones. So he followed that line in his novels. Especially in the novel "The Name of the Rose", set in the form of a historical device, it is synthesized and presented to the reader in a world dominated by various chaos and uncertainty. In the novel "The Name of the Rose", which challenges the possibilities of logical postmodernism, the issues of religion, history, philosophy, medicine, the arts, and comedy are conveyed in a new world against the background. Eco, who created the text in the text, also created an idea. Starting with the name he chose for the novel, Eco intends to challenge the reader. The Eco notes:

"My novel has another title: The Monastery of Crime. I put this aside, because it only attracted the reader's attention to the detective issue, and from the beginning of the story, the unfortunate recipients could drag them to a book that would deceive them. I liked it when the idea of the name of the flower came to my mind at random, because the flower is so symbolic that it is almost a symbolic object. Live the lives of mysterious roses and one roses, two roses wars, one flower is a flower, the flowers, the beauty of extraordinary flowers, the beautiful scent of fresh flowers. The name of a book should not confuse the ideas, nor put them together [3, c. 700-701].

The title of the Golden Roses is an Eco labrint from beginning to end. However, the reader who thinks the end of the work and the neglected attitude of Eco's views on the work thinks that Eco is sitting and laughing at the reader. However, the labrint shaped device, which we assume to be open to all these ideas and subsequent thoughts on Eco's novels, continues. As Calvino did not talk about himself, he even confused the reader with false ideas. All this is a labyrinthine device of the postmodern writer's brain, intertwined with semiology. Postmodern novel writers' lives are wiped out. Or it is a divine device. "The creativity of Eco closely reflects the characteristics of postmodern writing, such as on-device and interdisciplinary" [15].

These features are the main genetic codes of the modern postmodern novel. Many postmodern artists combined with Semiotic shades appear in the background of the double reality of their postmodern works. "The reality of postmodernism is a fact that neither metaphysics nor physics refers to. This is "the third hippereal / supernatural, which is a reference to the geographical, virtual world, that is, virtual reality" $[8$, c. 81$]$.

The name of the work in the title "The Name of the Rose" reflects many of the medieval Semootic shades. This name is simply symbolic. Although it is a novel with a different plot line, a series of incidents that resonate in the mind of an empirical reader who reads the name of the work, Eco is wearing a very realistic postmodern dress. From the prism of Umberto's thinking as a postmodernist, the book 
"The Confessions of a Young Novelist", which contains Eco's most interesting ideas about the novel The Name of the Roses, is extremely important.

The notes in that book are of importance to Umberto Eco's thinking system from its scientific influence. Events are taking place in medieval Europe. Eco writes about it: I wrote the name of the Golden Roses in just two years, and the only reason was that I didn't need to do medieval research. As I said, my thesis was about medieval aesthetics. There were other studies of the Middle Ages. For years, I have visited many Gothic cathedrals, built in the style of Roman architecture (I'm trying to make a break here. The theme of the daughter flower is the main design in most Gothic cathedrals. Most postmodern authors use these patterns and symbols). When I decided to write a novel, I felt like I had opened a large bookcase where I collected my documents from medieval information [5, c. 15].

Eco admits that he has created a postmodrn work in his articles. As I mentioned in my thoughts on "The Name of the Rose", I knew from the very beginning that postmodernism was at least two postmodern techniques. One of these is inter-Iranian irony: Reference from other known texts, or addressing them in the beginning. Redirect Replication. The second is the top explanation: the thoughts that come from the writer when he or she addresses the reader directly. The binary encoding is the use of inter-Iranian irony with coherent head-on explanation. The term was discovered by architect Charles Jencks, who believes that postmodern architecture addresses at least two levels at the same time. He notes that the postmodern structure or artwork appeals to both minorities, ie to a select group that uses superior codes, and to a broader mass of people who use popular codes [5, c. 30].

Apparently Eco uses binary coding, but has kept the focus on the elite layer in the work. Both systems, including the novel The Name of the Golden Rose, are one of the most important works of intellectual postmodernism directed at the elite, with the most superior codes. Umberto Eco begins with the translation of a manuscript found in the novel "The Name of the Rose". As he said, there is binary encoding here. In other words, the writer addresses another author's novel, "The Crusades", by the great Italian novelist Allessandro Monzon.

The most important notion that Charles Jencks presents in the history of postmodernism is "binary coding". Therefore, the postmodern architecture is capable of addressing two different masses in different layers with the ability of double coding; to the elite and to the wider masses. "The Name of the Rose", which is full of appeals to the elite, con- tains both descriptions of the masses. But this image is not heartbreaking, or the moment when it begins to open. "Barthes goes one step further by addressing Kristeva's integrity, focusing on the fact that the text does not create all of it, and that the text resonates with other texts. In this context, a text is presented to readers as a reflection of pre-written texts and therefore the previous text or texts create a later source of text" [10, c. 22-23].

As we have already mentioned, many of Eco's works are related to any pre-existing text or story or historical event. It sends postmodern replicas to the same event. Eco's notes in the book "Confessions of a Young Novelist" reveal that the writer's device was able to attract readers' attention, including the fact that Eco's wife was an art historian and that his own medieval study also played a part in Eco reality.

Eco notes that after the publication of "The Name of the Rose" many readers wrote me a letter and said they had found a monosote in my story. There were those who wanted to know more about the handwriting I mentioned in the book presentation. In the same way, I say that he found an anonymous book by Athanasius Kircher on the same page in Bounes Aires (a bookstore selling ancient and rare books). About 30 years after the release of my new novel, a German writer wrote to me and said he had found Kircher's book on the Bounes Aires [5, c. 62].

Another version of a similar confession, Gustave Flaubert, wrote in a letter to Luis Colette: "Not yesterday, but the day before, I found cigar brushes and cake scraps in a beautiful waterfront in the Touques forests. Some people had a picnic here. In my November novel (November), eleven years ago, I described such a picture. My description was completely imaginary, but it came true the next day. I believe that everything a writer creates is true. The poem is as true as the geometry. Induction is the right way to reach all" [20].

It should be noted that in Eco's novels, both the text and the theme are so mastered that many readers believe that the event is either real or psychological. Sometimes even the reader gets overwhelmed by the writer's brain. I want to draw a line that, as it is clear from Eco's later notes, most of the mono- graphic drawings and manuscripts in the work are the product of the author's imagination. The eco readers are also divided into two parts: the model and the empirical reader. The differences in the two readers' perceptions of the novel help to reveal the nature and essence of the message that the work gives to the community.

Has postmodernism always prevailed in Eco? The most comprehensive answer to this question can still be given by Eco. Eco, who spent the last years 
of his life in a positive mood, titled "From Buddhism to Madness", was released after the writer's death. Did Eco, who uses an anonymously present expression, say that postmodernism is far behind? The work from "Buddhism to madness" can be viewed as a new impetus in Econ's world of thought.

Eco's second work, published in 1988, is titled "Foucault's Pendulum", which is rich in transitions to alchemy and the theory of sorcery. The work is regarded as a model of postmodernism. The Romanlanguage dictionary is too short and has been compiled a catalog-dictionary called Foucault's Pendulum dictionary. In one of the eco interviews, Foucault's Pendulum said: "Many people think that I have written a fiction novel, but they are wrong - the work is completely real". Foucault (Foucault Pendulum) is a device that visually shows the reality of the Earth revolving around an arrow. In 1851 he was elected the inventor of the French Pantheon, after the inventor French scientist Jean-Leon Fucco. At first glance, the dancer's device is nothing short of complicated. It is a simple ball hanging from a dome of a tall building on a long rope (67 meters during the first trial) [19].

Eco notes that after the novel "The Name of the Rose" I thought I wrote everything about me. The author writes that there are two things that come to mind: "First, Leon Foucault was a dancer; I saw him in Paris thirty years ago and was very impressed; it was another excitement that had long been buried in the depths of my soul. The second image was to play a trombone at a funeral for members of the Italian Resistance Movement. I never bothered to tell this true story because I thought it was spectacular, and when I read Joyce I realized that I had lived what he (Stephen Herodo) said epic.

So I decided to write a story that started with a dancer and ended up with a young man playing a trombone in a cemetery on a sunny morning $[5$, c. 20$]$. The novel has caused a great deal of varied opinions by many researchers in the world of science. Except for the irony and interdependence in the novel, the work does not refer to any novel type. A novel that fits the category of Eco Count or a science novel is like a brain with its heavy language and theme transitions and colors. However, I note that Eco himself is referring to the characters in the work: "Belbo is a sane but Iranian language (really postmodern in terms of excessive use of literary explanations)" in the secret files of Belbo. In all his novels, Eco's creativity, which points to history, to any object, to man is to be multiplied.

"The postmodern novel is no longer the object of doubt because of the skepticism of the notion of 'past reality' in history. Not staying true to historical truth is a kind of freedom to write" [9, c. 43]. The language of the novel "Foucault's Pendulum" is extremely heavy. The abundance of topographies and interlocutors, and the intellectual abundance of these, further complicate the "Foucault's Pendulum".

Umberto Eco's "Six Walks in the Fictional Woods" (1993) is similar to Italo Calvino's American Lessons. Eco also begins his work by remembering Calvin. The creativity of these two writers has evolved in parallel with the creation of both writers of the same era, which led to the interest of both of them in the same way, and would later become prominent figures of postmodernism. Calvino's. "If on a winter's night a traveler" by Eco's "Lector in fabula" Reader's Role Eco responds to the novel's comparisons: "Those who compare Calvino's novel" A Winter Night if a Traveler "with my work can regard my work as a novel commentary on his novel. But this is not the case, both works were published almost simultaneously" [6, c. 12].

When Calvino sent me his book, he should have got my book, because a post I wrote was a quote (Superior stabat lupus, longeque inferior agnus, that is, above the Kurdish river, below the lamb). As can be seen, even in the dialogue between the two authors, one of the main features of postmodernism is the use of text signification, irony, and binary coding. "Open work" is the main criterion of postmodernism. The book, which has been heavily criticized since its inception, seeks to identify the postmodernism as a fact. "It is like a machine that produces interpretations that are rewritten at every meeting with a postmodern reader called" Open Text "by J. Derrida's philosophy that" every text is a different text" 7, c. 30].

The open-minded creativity of the ecosystem recognizes the possibility of many personal interventions, but the interventions that are to be made should be non-personal, non-personal and not of any kind. The open structure of the text, the obligation of the reader, is not a one-way invitation. Rather, it is a call that recognizes the possibility of directing it to the text [4, c. 32].

Postmodernism has a special place in the thinking of the peoples of the world. The first research book on postmodernism in Azerbaijan is the book "Umberto Eco and the Philosophy of Postmodernism", written and written by Narmin Kamal. Taking a look at the postmodern theory of Umberto Eco's creativity, the author believes that Azerbaijan should definitely use the goals of postmodernism. In addition to Umberto Eco's creations, the book also focuses on the philosophy of postmodernism. In addition, there are many writers in the environment who are aware of the bridges of intellectual postmodernism created 
by Eco. We will not mention poetry as our research covers the postmodern tendencies in the artistic life of Azerbaijan in the context of European literature. However, it is worth noting that postmoderism in the field of poetry is also relevant in Azerbaijan.

In the field of prose, postmodernism seeks to be understood in the context of scientific articles. As if the authors were writing some kind of postmodernism and learning it. Our dear critic, literary critic Tehran Alishoglu writes: "It is precisely the postmodernism of the 2000s: marginal culture, deconstruction, destruction, quotation poetry, author's death, pastime, space, profes- sionalism. concepts such as national literary practice are also looking for a way to theoretical evolution. This is evident from the postmodernism's position as a literary position (for example, in the publicist writings of Gan Tural, Seymour Beijing, and Agshi), attempting to create a peculiar national postmodernism theory ("Heroschy's" freemasonry) [18].

Like Eco postmodern tendencies in the Azerbaijani artistic era of independence are first seen in the work of Kamal Abdulla, the creator of intellectual postmodernism in Azerbaijan. The best example of this is the common tendencies in the title "The Name of the Rose" and "The Incomplete Manuscript". The creativity of Kamal Abdulla, who introduced the eco-modern postmodernism in a new version of literature, is extremely important in this regard. In particular, issues such as re-focusing on the past, metaphorics, binary coding, paste, labrint effect, and open text (such as the persistent text input of the reader) are widespread in the works of K.Abdulla. Vitorio Strada described the work "The Name of the Rose" as a requirement of today's culture, which combines the past and present cultures [12, c. 71-89].
Conclusions. The same can be said about the "The Incomplete Manuscript". Both works are based on the same idea, and both novels depict traditional themes. U. Eco creativity is found in such elements as paste and intertextuality. There are examples of pasties in Azerbaijani literature. And let's note that, especially in the presentation of young writers, paste in Azerbaijani literature has come up with very interesting trends.

According to Jameson, this logic, where reality is transformed into images, is called "pasture, a humorous, empty parody". Thus, the exact and irreplaceable aesthetic values of the past (Modernism) (Parody) have become increasingly used in postmodern culture [15, c. 344]. Qismat writes: "Pastis" is a quote - one of the most important conditions in post-modernist literature. Even a group of people in Europe have filed a lawsuit to officially recognize paste as a new religion [17].

According to Salida Sharifova, the signs of paste in the Azerbaijani literature are manifested in the "Desert "novel by Karamat Boyukchol. The work draws attention to the fact that the saga is presented in a modern modeling plot line [14, c. 35]. In addition, we come across an example of paste in the work of Kemal Abdulla's "The Incomplete Manuscript", Gan Turali's "The Falcon Fighter" and "18.6" work by Seymur Baycan.

Other elements of postmodernism are also included in the Azerbaijani literature. The creativity of Eco, one of the pioneers of postmodernism, played an extremely important role in the development of the Azerbaijani literary generation and understanding of the theory of postmodernism. Post-modernist movements such as Eco, which Eco shaped before his works, are set out in the peculiar prose examples of his later writing. This is a kind of postmodern experience and postmodern wins.

\section{REFERENCES:}

1. Allen G. Intertextuality (New Critical Idiom). London; New-York : Routledge, 2000, 238 p.

2. Akalin S.H. Turkish Glossary - Interdisciplinary Articles, Ankara : Turkish Language Institute Publications, (2011). $1667 \mathrm{p}$.

3. Eko U. (2019). Gülün Adı. Şadan Karadeniz (Çev, 48. bs.), İstanbul : Can Yayınları. 732 s.

4. Eco U. The Open Work (Trans: Pinar Savash), Istanbul, 2001, Publication of Can, 344 p.

5. Eco U. Confessions of a young romance. İstanbul, 2017, Red Kedi. 192 p.

6. Eco U. "Six Walks in the Fictional Woods" (Sei passeggiate nei boschi marrativi). Turkey, 2019, Publication of Can. $186 \mathrm{p}$.

7. Kamal N. Umberto Eco and the philosophy of postmodernism, $140 \mathrm{p}$.

8. Karaca A. "1970'ten Günümüze Roman”, 2007, Türk Edebiyatı, 401 s.

9. Karabulut M., Biricik I. "Postmodern Edebiyatın Ne'liği" HiKMET-Akademik Edebiyat Dergisi [Journal of Academic Literature], Gelenek ve Postmodernizm Özel Sayısı, Yıl 3, 2017, S. 34-45 Yükleme Tarihi: 12.04.2017. Kabul Tarihi, 30.05.2017.

10. Öğeyik M.C. Metinlerarasılık ve Yazın Eğitimi, Ankara : Anı Yayıncııı, 2008, 128 s.

11. Rifat M. Yüzyılda Dilbilim ve Göstergebilim Kuramları. İstanbul : Yapı Kredi Yayınları, 2019. $250 \mathrm{~s}$.

12. Страда В. Модернизация и постмодернизация // Окно в свет, 1999, № 2, С. 71-89.

13. Semiotic codes of mass media. A.N. Karimova, T.T. Kahramanova. The News of Baki University, № 1, Series of Humanities, p. 207. 
14. Şərifova S.Ş. Çağdaş Azərbaycan postmodern romanı. Bakı : “Elm və təhsil”, 2015, 104 s.

15. Yılmaz Z.S. Umberto Eko'nun “Gülün adı” romanında anlatıcı ve kurmaca dünya. Uluslararası Sosyal Araştırmalar Dergisi / The Journal of International Social Research Cilt: 11 Sayı: 55 Şubat 2018 Volume: 11 Issue: 55 February 2018.

16. http://etatist.com/xeber/2437-azrbaycanda-postmodern-slubda-bir-sr-yazlmayb.html.

17. http://etatist.com/xeber/2437-azrbaycanda-postmodern-slubda-bir-sr-yazlmayb.html.

18. http://yarpaq.az/az/tehran-elisanoglu-muasir-edebi-prosesin-tehlili-metodologiyasi-musteqillik-illeri-tecrubesinden/. 19. https://tr.sodiummedia.com/4173610-foucault39s-pendulum-and-its-influence-on-world-culture.

20. https://docplayer.biz.tr/5824096-Romanda-kurmaca-ve-gerceklik.html119 s.

УДК 821.111

DOI https://doi.org/10.32782/tps2663-4880/2020.14-2.38

\title{
СПЕЦИФІКА КОНЦЕПТУ ОСТРОВА В РОМАНІ «ДО МАЯКА» В. ВУЛФ
}

\author{
SPECIFICITY OF THE CONCEPT OF THE ISLAND \\ IN THE NOVEL "TO THE LIGHTHOUSE" BY W. WOLFE
}

\author{
Лозенко В.В., \\ orcid.org/0000-0003-1248-0534 \\ кандидат філологічних наук, \\ дочент кафедри латинської мови та медичної термінологї \\ Харківського національного медичного університету
}

\begin{abstract}
У статті досліджено літературні проєкції концепту острова в романі «До маяка» В. Вулф. Специфіка авторської інтерпретації полягає в тому, що концепт острова репрезентовано у творі як місце духовної подорожі героїв.

У творі представлено два острови - острів Скай та острів Гебридів. Особливу увагу слід звернути на віддалений острів Скай. Острів Скай втілює ідею утопічного місця, де панують ідилія та взаєморозуміння між людьми. Це місце фантазій, мрій, які сприймаються героями роману як реальні та існують у свідомості персонажів.

Характерна риса ініціації у романі «До маяка» В. Вулф виявляється в тому, що особистість здійснює пошук власних світоглядних орієнтирів, щоб зрозуміти та відновити теплі відносини в сім'ї (Кем, Джеймс), а також досягти рівноваги в житті (містер Ремзі).

Концепт острова має такі структурні складники, як символ човна, маяка, води, мотив подорожі. Мотив подорожі висвітлюється як важливий композиційний елемент, який доповнює зміст твору, виступає як засіб характеристики героїв. Іноді герої подорожують в уявному часі та просторі (подорож - оновлення свого «я» у Кем).

Символ човна пов'язується з мотивом подорожі, змін, переходу від одного психологічного стану (ненависті) до іншого (любові, ніжності, тепла). Символічна смерть старих відносин у сім'ї Ремзі зображується в переході (подорожі човном) через воду, у зв'язку з чим вимальовується модель «занурення у воду - очищення - оновлення».

Символ води відіграє важливу роль у романі «До маяка» В. Вулф. Назви водних об'єктів служать засобом характеристики героїв, яких часто порівнюють із представниками морської фауни (містер Кармайкл, місіс Мак-Неб). Самі герої виражають думки та почуття за допомогою слів, які асоціюються з водною субстанцією (to float - плавати, пливти; to flow - текти; to sink - потопати; to stream - відносити потоком; to spill - лити, проливати).

Символ маяка представляє справжнє «я» людини. Він виявляє глибоко приховані теплі почуття Джеймса до батька, а в самому містерові Ремзі вселяє почуття спокою та рівноваги.

За допомогою символів води і човна концепт острова в романі набуває нових рис - він характеризує глибокі духовні зміни персонажів, прагнення до пізнання власного «я», перемогу над егоїстичними бажаннями. Проводяться асоціативні зв'язки між концептом острова і людиною, внаслідок чого створюється метафора «людина-острів».

Ключові слова: концепт «острів», герой, символ маяка, мотив подорожі, символ води, мотив оновлення, символ човна, ініціація, метафора «людина-острів».
\end{abstract}

In the article the literary projections of the concept "island" are studied in the novel "To the lighthouse" by V. Woolf. The author's specificity of the concept "island" is that the island is represented as the place of spiritual travelling of characters.

Two islands are demonstrated in the work: the Isle of Skye and the Hebrides. The Isle of Skye conveys the idea of Utopian place where the idyll and mutual understanding among people are considered a priority. This is a place of fantasy, dreams perceived by characters of the novel in their consciousness as real ones.

The characteristic feature of initiation in the novel "To the lighthouse" by V. Woolf finds in the fact that a person is carrying out a quest of his / her own worldview items to understand himself / herself and to renew a close relationship with the family (Cam, James) and to achieve inner balance in life (Mr. Ramsay).

The concept "island" has such structural items as the symbol of a boat, the lighthouse, water, the motive of travelling. The motive of travelling is outlined as the important composing element which adds to the plot as the means of characters' evaluation. Sometimes characters travel in imaginary time and space (Cam's travelling-renewal of her own). 